DOI 10.4467/2543733XSSB.21.004.13797

ARTUR PATEK

Uniwersytet Jagielloński

\title{
SOPLICOWO NAD JARKONEM. PRÓBA PORTRETU ZBIOROWEGO POLSKICH UCHODŹCÓW WOJENNYCH W TEL AWIWIE $(1940-1948)^{1}$
}

\author{
Soplicovo over Yarkon. A Group Portrait of Polish War Refugees in Tel Aviv (1940-1948)
}

Summary

In 1939-1948, an important center of Polish pro-independence emigration emerged in Tel Aviv. In January 1945 2,291 Polish civilian war refugees resided there (6,718 in all of the Holy Land). Palestine was at the time a Mandatory Territory of the League of Nations, governed by Great Britain.

The refugees created a community which differed from the local one. It had clear distinguishing features - it included a large percentage of ill and lonely persons who required care; it had a high rate of feminization, an atypical social and occupational structure (a high percentage of intelligentsia and freelance professions), and a varied ethnic and religious composition. The refugees included many members of pre-war elites, people of culture and politicians.

The majority of the Poles declared their attachment to national values. However, this was also accompanied by negative phenomena - political divisions and internal feuds. The unlikelihood of returning home in the near future led to frustration. In some people, war experiences weakened ethical and moral standards; some came into conflict with the law.

The lot of the Poles from Tel Aviv showed all problems of pro-independence emigration: (1) an interest in politics pervaded their lives; (2) material concerns caused increasing worry; (3) awareness of having no say in changing the political situation in the homeland.

Key words: Tel Aviv, Polish war refugees, Poles in Tel Aviv 1939-1948, collective portrait

Słowa kluczowe: Tel Awiw, polscy uchodźcy wojenni, Polacy w Tel Awiwie 1939-1948, portret zbiorowy

${ }^{1}$ Autor miał okazję zająć się problematyką ,polskiego Tel Awiwu” w artykule opublikowanym w Czechach pt. Polští váleční uprchlíci v Tel Avivu (1939-1948). Portrét prostředí, „Český časopis historický” (Praha), R. 117: 2019, č. 3, s. 613-636. Niniejszy tekst podejmuje nowe wątki i jest oparty na szerszej bazie źródłowej. 


\section{Tytulem wprowadzenia}

W dramatycznych momentach życie polityczne i kulturalne narodów i państw przenosi się na emigrację. W czasie drugiej wojny światowej w Wielkiej Brytanii działało dziewięć prawnie uznanych rządów na uchodźstwie ${ }^{2}$. Dla Polaków, w różnych okresach, rolę szczególną odgrywały Paryż i Londyn. W odniesieniu do tego ostatniego funkcjonuje nawet określenie „Polski Londyn” jako symboliczne centrum „,państwa polskiego na wychodźstwie". Wydaje się, że do tej grupy ośrodków, ważnych dla polskiego życia narodowego, można zaliczyć także Tel Awiw.

W latach czterdziestych uformowało się tam prężne środowisko emigracji niepodległościowej. Palestyna była wówczas terytorium mandatowym Ligi Narodów, zarządzanym przez Wielką Brytanię, a Tel Awiw jednym z głównych ośrodków tego kraju. O realnym znaczeniu danego środowiska nie świadczy jego liczebność, ale dynamika działań. Uchodźcom udało się stworzyć w Tel Awiwie rodzaj małej Polski³ ${ }^{3}$ Nie chodzi tu tylko o konkretne instytucje (oświata, prasa, organizacje etc.), ale o pewien etos wyrażający się w przywiązaniu do Ojczyzny. Wprawdzie polskie środowisko nie było monolitem, istniały głębokie podziały polityczne i personalne, jednak stanowiło ono rodzaj wspólnoty.

Publicysta i dziennikarz Tadeusz Sypniewski (1907-1998), którego wojna rzuciła na Bliski Wschód, określił tę wspólnotę jako „telawiwskie Soplicowo"4. To ciekawe porównanie. Co wspólnego z Polakami w Palestynie może mieć szlachecki zaścianek, opisany przez Mickiewicza w Panu Tadeuszu? Jak wiadomo, Soplicowo to miejsce fikcyjne, wytwór literacki. Zarazem określenie symboliczne - metafora kraju rodzinnego. „Wpadam do Soplicowa jak w centrum polszczyzny; Tam się człowiek napije, nadyszy Ojczyzny!” - mówi jeden z bohaterów Mickiewiczowskiego poematu ${ }^{5}$. A zatem miejsce, które emanuje przywiązaniem do Ojczyzny.

Tel Awiw był miastem ważnym również dla żydowskich emigrantów z Polski. Przyjeżdżali do Palestyny, ponieważ Brytyjczycy obiecali, że stworzą tu ,żydowską siedzibę narodową" (Deklaracja Balfoura, 1917). Według szacunków miejscowego Konsulatu RP, w 1936 r. co drugi mieszkaniec Tel Awiwu pochodził z Polski (miasto miało wtedy około 120 tys. ludności) ${ }^{6}$. Wielu z nich czuło potrzebę kontaktu z językiem Mickiewicza. Stworzyli tu, nad rzeką Jarkon, swego rodzaju enklawę polsko-żydowskiej kultury. Zaczęła się ona kształtować wcześniej niż „,telawiwskie Soplicowo” i istniała dłużej. Sprawy te zasługują na osobną uwagę.

${ }^{2}$ Łącznie z Francuskim Komitetem Narodowym. H.L. Scanlon, European Governments in Exile, Washington 1943; M.D. Brown, Stanowisko Foreign Office wobec rzadów i komitetów na uchodźstwie w Wielkiej Brytanii podczas drugiej wojny światowej, [w:] Rzqdy bez ziemi. Struktury władzy na uchodźstwie, red. R.P. Żurawski vel Grajewski, Warszawa 2014, s. 303-320.

${ }^{3}$ Dostrzegła to również miejscowa społeczność żydowska, o czym świadczył tytuł notatki prasowej: B. Zanger, Poland in Palestine, ,The Palestine Post” (Jerusalem), 30 IV 1941, s. 4.

${ }^{4}$ T. Syp. [Tadeusz Sypniewski], Tel-Avivskie Soplicowo, „Biuletyn Informacyjny Polskich Uchodźców Wojennych na Bliskim Wschodzie” (Jerozolima), nr 12 (18 V 1941), s. 3.

${ }^{5}$ A. Mickiewicz, Pan Tadeusz, Księga VII, wersy 348-350.

${ }^{6}$ M. Szulkin, Żydzi palestyńscy w świetle raportów polskiej stużby dyplomatycznej, cz. II (1936-1939), „Biuletyn Żydowskiego Instytutu Historycznego” 1981, nr 1 (117), s. 64. Polski konsulat w Tel Awiwie został powołany w 1932 r., a w 1940 r. przekształcono go w Konsulat Generalny. Polska stużba zagraniczna po 1 września 1939 r., Londyn 1954, s. 62. 
Mimo geograficznej odległości z Tel Awiwem związanych jest sporo wątków dotyczących Polski. Nie jest to zagadnienie dziewicze, ponieważ o pobycie uchodźców w Ziemi Świętej już pisano ${ }^{7}$. W tym kontekście poruszano także sprawy telawiwskie, ale głównie na marginesie szerszych rozważań. Warto przyjrzeć się tym kwestiom i podjać próbę przedstawienia portretu zbiorowego polskiej społeczności uchodźczej w Tel Awiwie. Celem niniejszych uwag nie są dzieje tej zbiorowości, ale ukazanie jej specyfiki. Czym charakteryzowała się omawiana mikrospołeczność? Jaki był rodowód tej grupy, jak wyglądały jej troski i system wartości?

\section{Geneza - kontekst - cezury}

Trudno sobie wyobrazić, ale jeszcze na początku XX wieku w miejscu, gdzie dzisiaj rozciąga się Tel Awiw, były nadmorskie wydmy i nieużytki. Geograficznie i kulturowo usytuowany na styku Zachodu oraz świata Orientu od początku przyciagał imigrantów z Europy, w tym także z Polski. Ludziom kierującym się ideałami syjonistycznymi łatwiej było zadomowić się tutaj niż w Jerozolimie, gdzie czuło się obecność historii i religii. W przeciwieństwie do „Świętego Miasta” Tel Awiw (którego nazwę można przetłumaczyć jako „Wzgórze Wiosny”) uosabiał nowoczesność i młodzieńczą energię. W latach trzydziestych był uważany za gospodarcze i kulturalne centrum Żydów palestyńskich. Przybysze ze Starego Kontynentu nadali mu europejski charakter.

W 1940 r. Wielka Brytania zgodziła się na rozmieszczenie w Ziemi Świętej polskich uchodźców wojennych, a następnie na czasowe rozlokowanie wojska. W sierpniu i wrześniu 1943 r. przegrupowano do południowej Palestyny, wydzielony z Armii Polskiej na Wschodzie (APW), 2. Korpus pod dowództwem gen. Władysława Andersa. Po skierowaniu korpusu do Egiptu, a następnie na front włoski, jednostki, które pozostały, weszły w skład nowo utworzonego związku taktycznego pod nazwą Jednostki Wojska na Środkowym Wschodzie (JWSW) ${ }^{8}$. Obecność polskich formacji miała kluczowy wpływ na życie emigracji wojennej.

Uchodźcy cywilni przybyli w dwóch etapach. Najpierw przez Bałkany napłynęli uciekinierzy z Polski, zajętej przez III Rzeszę i Związek Radziecki. Później pojawili się zesłańcy i więźniowie sowieckich łagrów, którym w 1942 r. udało się wydostać z ZSRR z wojskiem gen. Andersa. Ewakuacja do Palestyny nie miała charakteru masowego, gdyż Ziemia Święta wraz z Egiptem i Irakiem była terenem koncentracji wojsk alianckich.

Pierwsi wojenni tułacze pojawili się z końcem 1939 r. Docierali na własną rękę. Właściwe skupisko zaczęło formować się jesienią 1940 r., gdy za zgodą władz brytyjskich rząd RP rozpoczął ewakuację do Palestyny uchodźców przebywających na Węgrzech, w Ru-

${ }^{7}$ Przykładowo: J. Draus, Oświata i nauka polska na Bliskim i Środkowym Wschodzie 1939-1950, Lublin 1993; J. Pietrzak, Polscy uchodźcy na Bliskim Wschodzie w latach drugiej wojny światowej. Ośrodki. Instytucje. Organizacje, Łódź 2012.

${ }^{8}$ Szerzej zob. Polskie Siły Zbrojne w drugiej wojnie światowej, vol. 2, Kampanie na obczyźnie, cz. 2 , wyd. Komisja Historyczna Polskiego Sztabu Głównego w Londynie, Londyn 1975, s. 299-344; T. Kondracki, Jednostki Wojska na Środkowym Wschodzie 1944-1947, „Teki Historyczne”, T. 23, Londyn 2004, s. 230-253; S. Zarzewski, Czasy nadziei. Działalność oświatowo-polityczna w JWSW, Londyn 1972; P. Żaroń, Armia Andersa, Toruń 2000, s. 214-235. 
munii i Jugosławii. Byli wśród nich przedstawiciele inteligencji oraz ludzie związani z dawnym obozem władzy, którzy czuli się zagrożeni po upadku Polski. Do Tel Awiwu w pierwszej kolejności kierowano rodziny z dziećmi w wieku szkolnym. Po ewakuacji wojska polskiego z ZSRR w 1942 r., dołączyły do nich (via Iran) rodziny żołnierzy, zwolnieni i urlopowani z wojska, inwalidzi wojskowi ${ }^{9}$.

Miasto, do którego Polacy przybywali, było dla większości nieznane. Wszyscy słyszeli o Jerozolimie, ale Tel Awiw leżał na uboczu szlaków turystyczno-pielgrzymkowych. Tymczasem okazał się on dla polskich wygnańców miejscem w jakiś sposób swojskim. Na ulicach rozbrzmiewał język Mickiewicza, a w sklepach i urzędach można było rozmówić się po polsku ${ }^{10}$. To nie [...] Bagdad czy Damaszek. To europejskie miasto $w$ stu procentach - zanotował jeden $z$ wojennych emigrantów ${ }^{11}$. Ułatwiało to Polakom odnalezienie się w nowym dla nich otoczeniu.

Sytuacja uchodźców zmieniła się w lipcu 1945 r., gdy Wielka Brytania wycofała uznanie władzom RP w Londynie. Kontrolę nad placówkami związanymi z rządem na emigracji przejęli Brytyjczycy. Oznaczało to, że o losach polskich uchodźców nie będą już decydowali Polacy. Dalszą opiekę nad wygnańcami sprawowali kolejno: brytyjski Interim Treasury Committe for Polish Affairs (ITC), następnie od jesieni 1946 r. United Nations Relief and Rehabilitation Administration (UNRRA), a od lipca 1947 r. International Refugee Organization (IRO) ${ }^{12}$.

Tel Awiw był domem dla polskich tułaczy krótko, niespełna osiem lat. W latach 1947-1948 prawie wszyscy wyjechali. Wojskowi i członkowie ich rodzin zostali ewakuowani do Wielkiej Brytanii. Część Polaków IRO przewiozła do francuskiej strefy okupacyjnej Niemiec (obóz przejściowy Zech-Lindau) ${ }^{13}$, a część przyjął sąsiedni Liban ${ }^{14}$. Do Polski powróciła mniejszość, do połowy 1947 r. z okręgu telawiwskiego repatriowało się zaledwie około 400 osób pobierających uchodźczy zasiłek ${ }^{15}$. W Tel Awiwie pozostali m.in. uchodźcy o korzeniach żydowskich oraz ci, którzy założyli tu rodziny lub w jakiś sposób się urządzili.

Z Bliskim Wschodem nie wiązano nadziei na stałe osiedlenie. Nie sprzyjała temu sytuacja wewnętrzna w krajach tego regionu, a w Palestynie zaostrzający się konflikt arabsko-żydowski.

\footnotetext{
${ }^{9}$ Archiwum Akt Nowych w Warszawie, zespół Ministerstwo Pracy i Opieki Społecznej (dalej: AAN, MPiOS) 94, Sprawozdanie Tadeusza Lubaczewskiego z działalności Delegatury Ministerstwa Pracy i Opieki Społecznej w Palestynie za okres od 1 IV 1941 do 31 III 1942 r.; J. Pietrzak, op.cit., s. 49-53.

${ }^{10}$ Instytut Polski i Muzeum im. gen. Sikorskiego w Londynie (dalej: IPMS), A 9 VII/8, „Sprawozdanie Referatu Narodowościowego dla Mniejszości Żydowskiej Placówki Ministerstwa Spraw Wewnętrznych”, Jerozolima, luty 1945 r., k. 18-19. Konsulat Generalny RP szacował, że w mieście i jego okolicach językiem polskim posługiwało się około 30 tys. osób, żydowskich emigrantów z Polski. IPMS, A 49/90, ,Sprawozdanie statystyczne Konsulatu Generalnego RP w Tel-Aviv na dzień 2 I 1944 roku”, k. 195.

${ }^{11}$ Cyt. za M. Czuchnowski, Cofnięty czas, Londyn 1945, s. 53.

${ }^{12}$ Szerzej zob. J. Łaptos, Humanitaryzm i polityka. Pomoc UNRRA dla Polski i polskich uchodźców w latach 1944-1947, Kraków 2018.

${ }^{13}$ IPMS, A 11E/1230, „Sytuacja Polaków w Palestynie”, 16 II 1948 r. Wykazy ewakuowanych: The National Archives, London (dalej: NA), FO 371/72083, „Polonais de Palestine évacues en zone française”.

${ }^{14}$ K. Kantak, Dzieje uchodźtwa polskiego w Libanie 1943-1950, Bejrut 1950, s. 71-72.

${ }^{15}$ Biblioteka Polska POSK w Londynie (dalej BPOSK), Rps 1279, Papiery Stanisława Rosmańskiego, dok. 37: „Sytuacja w okręgu Tel-Aviv na dzień 1 lipca 1947 r.”
} 


\section{W świetle statystyki}

W maju 1941 r. w Tel Awiwie przebywało ponad pół tysiąca polskich uchodźców cywilnych ${ }^{16}$. W żadnym innym mieście w Palestynie nie było ich aż tylu ${ }^{17}$. Liczba ta znacząco wzrosła po ewakuacji Polaków z Iranu. W styczniu 1945 r., według danych Konsulatu Generalnego RP, w mieście mieszkało już 2291 wojennych emigrantów z Polski. Niewielka uchodźcza społeczność uformowała się także w pobliskiej Jafie (206 osób) ${ }^{18}$. Dodajmy, że w całej Palestynie było wtedy 6718 cywilnych tułaczy z polskim paszportem ${ }^{19}$. W rzeczywistości liczba Polaków mogła być wyższa, ponieważ ta statystyka uwzględniała tylko osoby pozostające w ewidencji Delegatury MPiOS Rządu RP w Jerozolimie.

Tel Awiw był jednym z dwóch głównych skupisk polskiego uchodźstwa cywilnego w Ziemi Świętej. Większość urzędów i placówek związanych z władzami RP na obczyźnie miała siedzibę w Jerozolimie, stolicy mandatu palestyńskiego. Ale więcej Polaków osiedliło się nad Morzem Śródziemnym. Przykładowo, według ewidencji Delegatury Polskiej Opieki ${ }^{20}$, w grudniu 1945 r. w Tel Awiwie przebywało 2378 uchodźców, a w Jerozolimie - 1568. W sąsiedztwie obydwu miast znajdowało się także kilka mniejszych polskich skupisk. Jeśli je uwzględnimy, okaże się, że w ośrodku telawiwskim (Tel Awiw, Rechowot, Jafa) mieszkało wtedy 3083 uchodźców, a w jerozolimskim (Jerozolima, Ain Karem, Ramallah, Betania) - 2349 ${ }^{21}$. Wyższe szacunki znajdujemy w datowanym na dzień 8 października 1945 r. sprawozdaniu Tomasza Malickiego, kierownika placówki Ministerstwa Spraw Wewnętrznych Rządu RP (uchodźczego) w Jerozolimie. Według niego w Świętym Mieście miało przebywać 2000 uchodźców (oraz $900 \mathrm{w}$ jego okolicach), a w Tel Awiwie około 3000 (i dalszych $900 \mathrm{w}$ sąsiedztwie miasta) ${ }^{22}$.

Oznaczało to, że ośrodek telawiwski skupiał więcej niż $40 \%$ Polaków, których lata wojny rzuciły do Ziemi Chrystusa. Począwszy od drugiej połowy 1947 r., w związku z ewakuacją z Palestyny, liczba wygnańców stopniowo kurczyła się (zob. tab. 1).

Czy Polacy (ci nieżydowscy) byli zauważalni wśród ogółu mieszkańców Tel Awiwu? Obiektywnie rzecz ujmując, stanowili niewielki odsetek, około 1,4\% ludności w 1944 r. ${ }^{23}$

\footnotetext{
${ }^{16} \mathrm{Nie}$ licząc osób, które przybyły na podstawie brytyjskich certyfikatów imigracyjnych. T. Syp., Tel-Avivskie Soplicowo.

${ }^{17}$ Według „The Palestine Post”, w Tel Awiwie mieszkało wówczas $80 \%$ polskich uchodźców w Palestynie (B. Zanger, op.cit.). Późniejsze szacunki, z początku 1942 r., mówiły o około $60 \%$. W Palestynie. Z życia uchodźctwa [!] polskiego w Tel-Avivie. Komunikat Prez. Komitetu Obywatelskiego w Tel-Avivie, „Głos Polski” (Tel Awiw), nr 2 (15 IV 1942), s. 5.

${ }^{18} \mathrm{~W}$ Tel Awiwie przebywała także niewielka grupa Polaków chrześcijan (około 15 osób), wywodząca się z emigracji przedwojennej. IPMS, A 49/90, Sprawozdania statystyczne Konsulatu Generalnego RP w Tel Awiwie na dzień 2 I 1944 i 31 I 1945 r., k. 195, 246.

${ }^{19}$ Ibidem, Raport Delegata MPiOS Kazimierza Jaroszewskiego do Konsulatu Generalnego RP w Tel Awiwie (27 I 1945 r.), k. 254, dane wedhug stanu na 31 XII 1944 r.

${ }^{20}$ Organ wykonawczy Palestine Government Committee for Polish Affairs, powołany przez Brytyjczyków po cofnięciu uznania rządowi emigracyjnemu. Zastąpił Delegaturę MPiOS.

${ }^{21}$ United Nations Archives, New York (dalej: UNA), UNRRA, S-1021-0151-13, „Information on Polish refugees in Palestine", 20 XII 1945 r., s. 1. Dane te obejmowały tylko osoby pobierające zasiłek.

${ }^{22}$ Liczbę polskich uchodźców cywilnych w całej Palestynie określił Malicki na 7142 osoby (bez młodzieży junackiej). Biblioteka Jagiellońska w Krakowie, Archiwum Domowe Pawlikowskich (dalej: BJ, ADP), sygn. 11855 IV, Sprawozdanie T. Malickiego z 8 X 1945 r., k. 86.

${ }^{23}$ Według szacunkowych danych z $1944 \mathrm{r}$. Tel Awiw liczył wtedy 166,7 tys. mieszkańców. The Statesman's Year-Book. Statistical and Historical Annual of the States of the World for the year 1947, ed. S.H. Steinberg, London 1947, s. 213.
} 
Z drugiej strony byli jedną z najliczniejszych w owym czasie chrześcijańskich mniejszości w tym niemal jednolitym narodowościowo mieście.

Tab. 1. Polscy uchodźcy cywilni w Tel Awiwie i Jafie (1942-1948) ${ }^{24}$

\begin{tabular}{lrrr}
\multicolumn{1}{c}{ Data } & Tel Awiw & \multicolumn{1}{c}{ Jafa } & \multicolumn{1}{c}{ Palestyna } \\
4 grudnia 1942 & 944 & 50 & 6718 \\
styczeń 1945 & 2291 & 206 & $7204^{\mathrm{a}}$ \\
grudzień 1945 & 2378 & 222 & $1183(1185)^{\mathrm{b}}$ \\
styczeń 1948 & 291 & 110 & $153(173)^{\mathrm{c}}$
\end{tabular}

a - osoby pozostające w ewidencji Delegatury Polskiej Opieki

b - zarejestrowani w IRO (druga wartość za: IPMS, A 76/26, Pismo RNUP...

c - istnieją różne wersje wykazu

Analiza oficjalnej statystyki przynosi dalsze ciekawe spostrzeżenia:

(1) Wśród polskich uchodźców cywilnych w Tel Awiwie i jego okolicach zdecydowaną większość stanowiły kobiety. Tak zwany współczynnik feminizacji, który określa przeciętną liczbę kobiet na 100 mężczyzn, był wyjątkowo wysoki i w 1944 r. wynosił około 138-140 (zob. tab. 2). Tak znaczące dysproporcje są charakterystyczne dla emigracji wojennej. Część kobiet mieszkała samotnie, gdyż ich mężowie i synowie służyli w wojsku. Innym najbliższych odebrała wojna. Niektóre niewiasty świadomie odkładały założenie rodziny na bardziej sprzyjający czas. Nie bez znaczenia był fakt, że w Tel Awiwie i Jafie uruchomiono kilka placówek zwyczajowo nazywanych Stacjami Opieki nad Matką i Dzieckiem. Znalazły w nich schronienie kobiety i dzieci z rodzin wojskowych oraz ochotniczki z Pomocniczej Służby Kobiet (PSK) ${ }^{25}$. Ponieważ większość tych placówek mieściła się w Jafie, rzutowało to na strukturę płci i wieku polskiej społeczności w tym mieście. Była ona bardzo nietypowa (zob. tab. 3). Według danych Delegatury MPiOS na dzień 1 stycznia 1945 r., wśród zarejestrowanych w Jafie 206 uchodźców znajdowało się jedynie dwóch dorosłych mężczyzn i aż 89 dzieci $^{26}$.

${ }^{24}$ IPMS, Kol. 25/23A, „Uchodźctwo Polskie w Ośrodku Tel-Aviv. Stan z dnia 4 grudnia 1942 r.”; ibidem, A 49/90, „Sprawozdanie statystyczne Konsulatu Generalnego RP w Tel-Aviv na dzień 31.1.1945 r.”, k. 246; ibidem, A 76/26, Pismo Rady Naczelnej Uchodźstwa Polskiego w Palestynie do Zjednoczenia Polskiego Uchodźstwa Wojennego w Brukseli, 5 I 1948 r.; ibidem, A 76/48, „List of Polish refugees in Palestine” (kwiecień 1948 r.); BPOSK, Rps 1279, Papiery S. Rosmańskiego, dok. 43: „Spis uchodźców w okręgu Tel-Aviv sporządzony na podstawie list płatniczych Delegatury Polskiej Opieki na dzień 1 stycznia 1948 r.”; ibidem, 1608, „Sprawy Bliskiego i Środkowego Wschodu. Miesięczny Komunikat Wewnętrzny Spółki Wydawniczej Reduta w Jerozolimie", no 4, 16 I 1948, s. 4; NA, T 236/1387, ,Excerpts from the report of the delegate of the audit department in Tel-Aviv on the accounts of the Polish Social Welfare in Jerusalem for July-December, 1945", s. 1; UNA, UNRRA, S-1021-0151-13, „Information on Polish refugees in Palestine”.

${ }^{25}$ AAN, MPiOS 94, Sprawozdania z działalności domów matki i dziecka w Jafie, styczeń i kwiecień 1944 r. (k. 155-161, 205-211, 213-219); M. Czuchnowski, Dom Kobiet (reportaż z Polskiej Stacji Matki i Dziecka), „Gazeta Polska” (Jerozolima), [dalej: GP] 28 III 1943, s. 4; Domy Matki i Dziecka, ibidem, 20 VII 1944, s. 4; Poświęcenie nowego „Domu Matki i Dziecka”, ibidem, 29 XI 1944, s. 4.

${ }^{26}$ IPMS, A 49/90, Pismo Jerzego Lechowskiego, kierownika Ekspozytury Delegata MPiOS, do Konsulatu Generalnego RP w Tel Awiwie, 29 I 1945 r., k. 256. 
(2) Większość wojennych emigrantów, zarejestrowanych jako cywilni uchodźcy, stanowiły osoby pochodzenia żydowskiego (zob. tab. 2). Według danych z 31 grudnia 1944 r., w Tel Awiwie i okolicy odsetek uchodźców wyznania mojżeszowego był znacznie wyższy (70\%) niż w odniesieniu do ogółu wychodźstwa polskiego w Palestynie $(42,8 \%)^{27}$. Powody, dla których ludzie ci chętnie osiedlali się w Tel Awiwie, są zrozumiałe, skoro dużą grupę jego mieszkańców stanowili Żydzi polscy.

(3) Prawie jedna trzecia zarejestrowanych uchodźców wcześniej wykonywała wolny zawód, mniej więcej połowa pracowała w przemyśle i handlu, rolnictwem zajmowała się nikła mniejszość (zob. tab. 2). Tymczasem w przedwojennej Polsce rolnictwo i leśnictwo stanowiło podstawę utrzymania 59,1\% ludności ${ }^{28}$. Przywołane dane (chodzi o Tel Awiw) dotyczą okresu już po przybyciu dawnych zesłańców z ZSRR. Wcześniej, przed 1942 r. odsetek inteligencji był jeszcze wyższy. Wpływ na tę specyficzną strukturę zawodową miały przynajmniej dwa czynniki: (a) na uchodźstwo, w poczuciu zagrożenia, udawali się w pierwszej kolejności ludzie wykształceni, (b) znaczący udział obywateli pochodzenia żydowskiego, wśród których ,góruje element inteligencko-kupiecki, raczej to, co w Polsce można by było nazwać górnymi warstwami społeczeństwa żydowskiego"29.

(4) Znacząca część uchodźców miała rodzinne powiązania z wojskiem. Nie udało się dotrzeć do dokładnych danych, ale o skali zjawiska możemy wnosić na podstawie obliczeń dotyczących osób pobierających zasiłek uchodźczy. Według preliminarza budżetowego Delegatury Polskiej Opieki na lipiec 1946 r., na ogólną liczbę 1249 uchodźców w Tel Awiwie, którzy pobierali to zaopatrzenie (nie uwzględniono tu jednak inwalidów), członków rodzin wojskowych było $266, \mathrm{tj} .21,3 \%{ }^{30}$. W sąsiedniej Jafie, gdzie znalazły się m.in. ochotniczki PSK, odsetek ten był o wiele wyższy i wynosił $55,7 \%{ }^{31}$.

Tab. 2. Polscy uchodźcy cywilni w okręgu Tel Awiw (1944 r. $)^{32}$

\begin{tabular}{|c|c|c|}
\hline & \multicolumn{2}{|c|}{$\underline{\text { Rozmieszczenie }}$} \\
\hline & 2 I 1944 & 1 I 1945 \\
\hline Tel Awiw & 2148 & 2291 \\
\hline Rechowot & 341 & 426 \\
\hline Jafa & 260 & 206 \\
\hline Razem & 2749 & 2923 \\
\hline
\end{tabular}

${ }^{27}$ IPMS, A 49/90, Raport Delegata MPiOS Kazimierza Jaroszewskiego, 27 I 1945 r., k. 254.

${ }^{28}$ C. Brzoza, A.L. Sowa, Historia Polski 1918-1945, Kraków 2006, s. 111. Dane za 1937 r.

${ }^{29}$ BJ, ADP, sygn. 11855 IV, Sprawozdanie T. Malickiego, k. 86.

${ }^{30}$ IPMS, A 76/46, „Preliminarz budżetowy Polskiej Opieki nad Uchodźcami w Palestynie na mies. lipiec, 1946 r."

${ }^{31}$ Ibidem.

${ }^{32}$ IPMS, A 49/90, Sprawozdania statystyczne Konsulatu Generalnego RP w Tel Awiwie na dzień 2 I 1944 i 31 I 1945 r., k. 195, 246. Jak można wnosić z cytowanych pism K. Jaroszewskiego z 27 I 1945 r. i J. Lechowskiego z 29 I 1945 r. (ibidem, A 49/90, k. 254 i 256), sprawozdanie Konsulatu Generalnego RP z 1945 r. podaje stan na dzień 1 I 1945 r. (względnie 31 XII 1944 r.). 


\begin{tabular}{|c|c|c|}
\hline & \multicolumn{2}{|c|}{ Podział według płci i wieku } \\
\hline Mężczyźni & 906 & 937 \\
\hline Kobiety & 1274 & 1296 \\
\hline Dzieci do 6 lat & 201 & 276 \\
\hline \multicolumn{3}{|l|}{ Dzieci w wieku } \\
\hline \multirow[t]{2}{*}{$7-18$ lat } & 368 & 414 \\
\hline & \multicolumn{2}{|c|}{$\underline{\text { Struktura zawodowa }(\mathrm{w} \%)}$} \\
\hline Rolnictwo & 5 & 10 \\
\hline Przemysł i handel & 65 & 50 \\
\hline Wolne zawody & 30 & 40 \\
\hline & \multicolumn{2}{|c|}{ Wyznanie } \\
\hline Chrześcijańskie & 1169 & 877 \\
\hline Niechrześcijańskie & 1580 & 2046 \\
\hline
\end{tabular}

Tab. 3. Polscy uchodźcy w Tel Awiwie i Jafie - struktura płci i wieku (1 I 1945 r.) ${ }^{33}$

$\begin{array}{lcr} & \text { Tel Awiw } & \underline{\text { Jafa }} \\ \text { Mężczyźni } & 832 & 2 \\ \text { Kobiety } & 993 & 115 \\ \text { Dzieci } & 466 & 89 \\ \text { Razem } & 2291 & 206\end{array}$

(5) Ponad połowa dzieci i młodzieży w wieku 7-18 lat pobierała naukę w polskich szkołach (zob. tab. 4). Wskaźnik skolaryzacji, który określa odsetek osób uczących się w stosunku do całej populacji w danym przedziale wiekowym, zmieniał się, ponieważ zmieniała się liczba Polaków w Palestynie. W przybliżeniu odpowiadał on współczynnikowi skolaryzacji tej grupy wiekowej w przedwojennej Polsce ${ }^{34}$. Powszechność nauczania była najwyższa w początkowym etapie edukacji (szkoła powszechna), natomiast malała wśród młodzieży, która ukończyła 14 rok życia, co wiązało się z ogólną prawidłowością w tym zakresie. Ponieważ wojna przerwała naukę, fakt, że znacząca część młodego pokolenia otrzymała warunki do dalszej edukacji, miał duże znaczenie. Specyfiką polskiej szkoły w Tel Awiwie było to, że uczniowie pochodzili „z różnych środowisk: wiejskich, rolniczych, miejskich, robotniczych, fabrycznych, urzędniczych i wielkomiejskich"35. Stwarzało to różne problemy, na przykład dzieci przybyłe z ZSRR wyraźnie różniły się pod względem zdrowotnym, na co wpływ miały warunki życia na Wschodzie (zesłanie, łagry etc.) ${ }^{36}$.

${ }^{33}$ IPMS, A 49/90, Pismo J. Lechowskiego z 29 I 1945 r., k. 256.

${ }^{34}$ Dla przedziału wiekowego 7-19 lat wskaźnik ten w styczniu 1939 r. wynosił w Polsce 59,5\%. Mały Rocznik Statystyczny 1939, Warszawa 1939, s. 19, 317, 321.

${ }^{35}$ IPMS, A 74/39, „,Sprawozdanie Publicznej Szkoły Powszechnej IIIgo stopnia w Tel-Aviv za rok 1943/44” (20 X 1944 r.), k. 5.

${ }^{36}$ Ibidem. 
Tab. 4. Edukacja polskich dzieci i młodzieży w okręgu Tel Awiw (1944 r. $)^{37}$

$\begin{array}{lrr} & \text { 2 I 1944 } & \text { 1 I } 1945 \\ \text { Dzieci i młodzież } & & \\ \text { w wieku 7-18 lat ogółem } & 368(100 \%) & 414(100 \%) \\ \text { Uczniowie } & 234(63,6 \%) & 216(52,2 \%) \\ \text { w tym: szkoła powszechna i początkowa } & 138(37,5 \%) & 128(30,9 \%) \\ \quad \text { gimnazjum i liceum } & 96(26,1 \%) & 88(21,3 \%)\end{array}$

(6) Polscy uchodźcy stanowili istotną część wiernych miejscowej katolickiej parafii w Jafie. Wniosek taki można wysnuć, analizując zapisy w parafialnej księdze zgonów. W latach 1943-1946 mniej więcej co trzecia imienna adnotacja w „Liber defunctorum” odnosiła się do zmarłych polskiej narodowości ${ }^{38}$. Zdarzało się, że kilka kolejnych pochówków na miejscowym cmentarzu rzymskokatolickim miało polski charakter ${ }^{39}$. Według szacunków, w 1946 r. w Jafie mieszkało 16,8 tys. chrześcijan, ale trzeba pamiętać, że wśród wyznawców Chrystusa większość stanowili wierni greckiej Cerkwi prawosławnej, a byli również maronici, koptowie i in. ${ }^{40}$

\section{Kawałek Polski}

Stare porzekadło powiada: „liczy się jakość, nie ilość”. Wydaje się, że dość dobrze oddaje ono specyfikę polskiej społeczności w Tel Awiwie. Na pierwszy rzut oka była ona liczebnie niewielka, a przy tym wyznaniowo i narodowościowo zróżnicowana. Toteż zdumiewa bogata aktywność polityczna, społeczna i kulturalna, jaką rozwinęli uchodźcy. Stało się tak, ponieważ przez Tel Awiw przewinęło się wielu przedstawicieli przedwojennych elit, ludzi wykształconych. W sensie liczbowym byli w mniejszości, ale istotny był potencjał, jaki reprezentowali. Polską inteligencję w Tel Awiwie tworzyli naukowcy, nauczyciele, lekarze, inżynierowie, prawnicy, ekonomiści, urzędnicy państwowi, wojskowi, literaci, dziennikarze, artyści i in. ${ }^{41}$

Na liście osób, których lata wojny rzuciły nad Jarkon, znalazły się znaczące postacie ze świata nauki, kultury i polityki: profesorowie Cezaria Baudouin de Courtenay Jędrzejewiczowa (etnograf), Alfred Laskiewicz (otolaryngolog) i Kazimierz Rouppert (botanik),

${ }^{37}$ Szkoły cywilne - szkoła powszechna, gimnazjum i liceum w Tel Awiwie oraz szkoła początkowa w Jafie. IPMS, A 49/90, Sprawozdania statystyczne Konsulatu Generalnego RP w Tel Awiwie na dzień 2 I 1944 i 31 I 1945 r., k. 194-195, 246; ibidem, Pismo Delegata Ministra Wyznań Religijnych i Oświecenia Publicznego, Stanisława Rzeżychy, do Konsulatu Generalnego RP w Tel Awiwie, 13 II 1945 r., k. 251.

${ }^{38}$ Przykładowo w 1943 r. w „Liber defunctorum” parafii w Jafie odnotowano 25 zgonów, w tym 9 Polaków; w 1944 r. odpowiednio 20 i 8, a w pierwszym kwartale 1946 r. wśród zmarłych parafian Polacy stanowili równo połowę (6 na 12). Saint Anthony’s Catholic Church, Tel Aviv-Jaffa, „Defunctorum 06 May 1932 - 22 Sept. 2005” (dalej: SAC), 1943 (nr 1-25), 1944 (nr 1-20, liczone do końca listopada), 1946 (nr 1-12, liczone do dnia 29 marca).

${ }^{39}$ SAC, ,Defunctorum...”, przykładowo: 1943 (adnotacje nr 11-12, 17-18, 23-25), 1944 (nr 16-17, 19), 1945 (nr 12-15, 17-19, 32-34), 1946 (nr 10-12).

${ }^{40}$ The Middle East: A Political and Economic Survey, ed. Royal Institute of International Affairs, LondonNew York 1950, s. 277.

${ }^{41}$ IPMS, A 49/90, Sprawozdanie Delegata MPiOS K. Jaroszewskiego, 27 I 1945 r., k. 254-255. 
byli premierzy Janusz Jędrzejewicz i Sławoj Felicjan Składkowski, pisarz i publicysta Melchior Wańkowicz, poeta Władysław Broniewski. Występowali popularni artyści Hanka Ordonówna, Paweł Prokopieni (śpiewak operowy) ${ }^{42}$. Z wojskiem gen. Andersa na krótko zawitali w mieście m.in. Jerzy Giedroyc (późniejszy redaktor paryskiej „Kultury”) oraz reżyser filmowy Michał Waszyński.

Polską społeczność tworzyły różne środowiska o różnych doświadczeniach: (1) cywile przybyli przed 1942 r., w dużym stopniu inteligencja; (2) dawni zesłańcy i więźniowie sowieckich łagrów; (3) wojskowi i rodziny żołnierzy APW; (4) Polacy żydowskiego pochodzenia i Żydzi obywatele RP, którzy wiązali swą przyszłość z powstającym państwem żydowskim. Środowiska te nie były monolitem. Osobną grupę (wcale sporą) stanowili na przykład urzędnicy i działacze związani z przedwrześniowym obozem władzy. Każda z tych zbiorowości wnosiła w życie uchodźstwa własne wartości i złożyła się na jego oblicze polityczne i kulturalne.

Polacy nie zamieszkiwali w sposób zwarty jakiejś części Tel Awiwu. Nie było polskiej dzielnicy. W większości wynajmowali pokój, albo tylko łóżko w pokoju wieloosobowym, w różnych częściach miasta ${ }^{43}$. Istniało jednak miejsce, gdzie spotykali się, gdzie toczyło się ich życie zbiorowe. Miejscem tym była ulica Allenby’ego (Allenby Road), jedna z głównych arterii miasta. Tutaj znajdowały się najważniejsze placówki. Tak się złożyło, że większość uchodźczych instytucji zajmowała pomieszczenia w jednym gmachu pod numerem dziewięćdziesiątym piątym. Przed wojną mieściła się tam siedziba oddziału Banku Polska Kasa Opieki SA (PKO SA) ${ }^{44}$. W budynku, poza placówką bankową, działały teraz Komitet Uchodźców Polskich (KUP) oraz Świetlica, a w jej ramach biblioteka, czytelnia i stołówka. Przy ulicy Allenby’ego, ale na przeciwległym krańcu (pod numerem dwudziestym pierwszym), znajdowała się Kaplica Polska. Nieopodal, przy Montefiore Street, działało polskie gimnazjum, liceum i szkoła powszechna ${ }^{45}$.

Wrażenie swojskości tego rejonu miasta potęgowały odwołujące się do polskich klimatów lokale i sklepy, które prowadzili urodzeni w Polsce Żydzi. Rzut kamieniem od polskich placówek znajdowała się restauracja „Rachel”, serwująca polskie dania, a nieopodal salon obuwniczy o swojsko brzmiącej nazwie „Warszawski”"46.

Ważnym adresem był kościół św. Piotra w pobliskiej Jafie, gdzie regularnie odbywały się nabożeństwa i msze w języku polskim oraz uroczystości religijne z okazji rocznic i świąt narodowych. Bywało, że podczas tych uroczystości Polacy wypełniali cały kościół i plac przed świątynią ${ }^{47}$.

${ }^{42}$ Polish baritone, „The Palestine Post”, 12 IX 1941, s. 4; The Ordonka. Poland's most famous diseuse, ibidem, 26 VIII 1943, s. 4; ibidem, 11 IX 1941, s. 2; 8 VIII 1943, s. 2 (anonse o występach); Koncert Hanki Ordonówny, GP, 31 VIII 1943, s. 4.

${ }^{43}$ L. Berger, Czy uchodźców w Palestynie czeka los Fellahów, „Tygodnik Polski” (Nowy Jork), 1946, nr $13(70)$, s. 6.

${ }^{44}$ Oddział Banku PKO SA w Tel Awiwie został uruchomiony w 1933 r. J. Tomaszewski, Polski bank w Tel Awiwie, „Almanach Żydowski 1998-1999”, Warszawa [1998], s. 20-33.

${ }^{45}$ Steimatzkiego przewodnik po Palestynie, Jerozolima 1942, s. 142; Przewodnik po Palestynie, Tel-Awiw 1942, s. 30; Adresy wtadz i instytucyj polskich w Palestynie, GP, 1 VII 1942, s. 4.

${ }^{46}$ „Ku Wolnej Polsce. Tygodnik Wojska Polskiego na Środkowym Wschodzie” (Kair), nr 10, 31 XII 1941, s. 25 (dział ogłoszeń).

${ }^{47}$ Trzeci Maja w Tel-Avivie, GP, 6 V 1942, s. 4; Nabożeństwo za spokój duszy Józefa Pilsudskiego w kościele św. Piotra w Jafie, GP, 22 III 1943, s. 4. 
Życie na wychodźstwie było trudnym doświadczeniem. Nadzieja na szybki powrót do wolnej Ojczyzny oddalała się, szczególnie po 1945 r. W tej sytuacji zrozumiała była chęć stworzenia namiastki życia narodowego na obczyźnie. Namiastkę taką mogły zapewnić własne instytucje i stowarzyszenia. Działania w tym kierunku podjęły zarówno londyńskie władze RP, wojsko, Kościół, jak i sami uchodźcy. Chodziło o zbudowanie autonomicznego organizmu, który dawałby poczucie więzi, szansę bycia wśród swoich, a więc i swego rodzaju bezpieczeństwo.

Uchodźcy dysponowali własnymi strukturami społecznymi, kulturalnymi i politycznymi. Mieli swoją reprezentację (KUP w Tel Awiwie) ${ }^{48}$, szkolnictwo, system opieki społecznej, służbę zdrowia, duszpasterstwo, ośrodek kultury, jadłodajnię. W Tel Awiwie ukazywały się polskie książki i czasopisma, które „wciąż trzymały rękę na pulsie wypadków w Polsce i w szerokim świecie w sprawie Polski" ${ }^{\text {"49 }}$. Ważną rolę odgrywała Ekspozytura Delegatury MPiOS. Do jej zadań należało m.in. zapewnienie bezpłatnej opieki zdrowotnej, wypłata zasiłku uchodźczego, przydzielanie zapomóg. Świadczenia te przysługiwały obywatelom polskim bez względu na narodowość ${ }^{50}$.

Zważywszy na stosunkowo szczupłe rozmiary tego środowiska, fenomenem była duża liczba organizacji i stowarzyszeń społecznych. Pełny wykaz obejmuje prawdopodobnie około 30 pozycjií ${ }^{51}$. Bardziej niż liczba uwagę zwraca różnorodność inicjatyw. Były wśród nich stowarzyszenia naukowe, zawodowe, polityczne, wojskowe, kombatanckie. Swoje zrzeszenia mieli inżynierowie, lekarze, nauczyciele, prawnicy, a także inwalidzi wojenni, młodzież (harcerze). To prawda, że żywot niektórych organizacji okazał się krótkotrwały, a działalność symboliczna. Ważniejsze było to, że wyrabiały one wśród uchodźców tak potrzebną inicjatywę. Były miejscem, gdzie pielęgnowało się polskie obyczaje i tradycje. Uczestnictwo w nich dawało możliwość spotkania ludzi o podobnych doświadczeniach, co miało duże znaczenie, zwłaszcza dla osób samotnych.

Na uchodźstwie wiele miejsc i placówek pełniło dodatkową rolę. I tak szkolnictwo nie miało wyłącznie aspektu edukacyjnego, ale przeciwdziałało wynarodowieniu i demoralizacji dzieci i młodzieży, umożliwiając kontynuowanie nauki w ojczystym języku ${ }^{52}$. Kościół poza posługą duszpasterską angażował się w działalność oświatową, kulturalną i opiekuńczą (opieka nad chorymi żołnierzami, sierotami) i był znakiem łączności z ojczystym

${ }^{48}$ Jadwiga G., Organizacja podstawa życia (z działalności Komitetu Uchodźców Polskich w Tel-Avivie), GP, 19 V 1943, s. 4; IPMS, Kol. 660/6, „Regulamin Komitetu Uchodźców Polskich w Tel-Aviv uchwalony na plenarnym posiedzeniu Komitetu w dniu 17.5.43".

${ }^{49}$ IPMS, A 9 VII/8, Sprawozdanie Referatu Narodowościowego, k. 22. Bibliografia polskich czasopism w Tel Awiwie, ukazujących się w okresie pobytu uchodźców, liczy około 20 pozycji. J. Kowalik, Bibliografia czasopism polskich wydanych poza granicami Kraju od września 1939 roku, t. 1-4, Lublin 1976 (nr 330, 475, 483, 550, 609, 852, 1264, 1403, 1435, 1634, 1916, 1966, 2587, 2647, 2692, 3309, 3491, 3742, 3897).

${ }^{50}$ Rzad Polski - dla uchodźctwa. Na marginesie 2-lecia Delegatury M.O.S. w Palestynie, GP, 21 II 1943, s. 3 .

${ }^{51}$ AAN, Akta Antoniego Pająka i jego rodziny, sygn. 20, „Spis organizacji polskich i związków w Palestynie”, 7 II 1945 r., k. 2 (podaje 18 organizacji); ibidem, „Wykaz Polskich Organizacji Społecznych w Palestynie uprawnionych do wysłania po dwu Delegatów na Zjazd Przedstawicieli Polskich Organizacji Społecznych, który odbył się w niedzielę dnia 26 stycznia 1947 roku w sali Nowego Domu Polskiego w Jerozolimie", k. 2-3 (23 organizacje); BPOSK, Rps 1279, Papiery S. Rosmańskiego, dok. 9: „Wykaz organizacyj i stowarzyszeń okręgu Tel-Aviv", 16 II 1947 r.? (podaje 28 organizacji).

${ }^{52}$ J. Draus, Szkoly polskie w Tel-Awiwie 1940-1947, „Rocznik Komisji Nauk Pedagogicznych”, t. 39, Kraków 1987, s. 113-126. 
krajem i wiarą ${ }^{53}$. Z kolei polska nekropolia (a właściwie osobna kwatera na cmentarzu katolickim w Jafie) miała znaczenie dla zbiorowej świadomości uchodźców. Utrwalała pamięć o korzeniach i integrowała polską wspólnotę. W latach 1941-1948 pochowano tutaj ponad 60 Polaków. Byli wśród nich przedstawiciele uchodźczej elity: kawalerowie Orderu Virtuti Militari, urzędnicy państwowi, parlamentarzysta, małżonka ostatniego przedwojennego premiera II RP ${ }^{54}$.

Życie ma jednak swoje wymagania i telawiwscy Polacy nie poświęcali całego czasu sprawom narodowym. Tak jak w Kraju brali udział w życiu towarzyskim, czego świadectwem były pełne sale na koncertach, przedstawieniach teatralnych i dancingach. „Dnia 9-go, 13-go i 16-go listopada 1941 r. o godz. 19.30 - czytamy w jednym z ogłoszeń prasowych - Polski Teatrzyk Literacko-Artystyczny przy Komitecie Uchodźców Polskich w Tel-Avivie wystawia rewię w 2 częściach i 14 obrazach p.t. Porzqdek musi być! pióra Zenona Wardana"'55.

Życie towarzyskie toczyło się późnymi wieczorami, gdy słońce nie przypiekało już tak mocno. Zapełniały się uliczne stoliki i kawiarnie, gdzie wymieniano się najnowszymi wiadomościami. „Wszyscy się wówczas znali, wszyscy wszystko o sobie wiedzieli" ${ }^{56}$. Wśród wojskowych popularnością cieszyła się kawiarnia Friedmana nad morzem. „Gdzie ja jestem?" - dziwił się Ludwik Lawiński (popularny przed wojną aktor rewiowy). „W Warszawie, czy w Tel-Avivie? Wszystkie stoliki zajęte, a przy stolikach - mój Boże - sami Wielcy Znajomi: Bracia Jędrzejewicze, gen. Jur-Gorzechowski, gen. Krzemieński, gen. Składkowski i wielu, wielu innych"57.

Miejscowa prasa polska regularnie donosiła o sprawach ważnych i mniej istotnych, tworząc unikalną kronikę życia codziennego uchodźców. Mamy zatem doniesienia i komunikaty o wypłacie zasiłków, zebraniach stowarzyszeń, dyżurach ośrodka zdrowia czy poszukiwaniach członków rodzin rozdzielonych przez wojnę. Równolegle pojawiają się także inne treści. Reklamuje się Fabryka wódek, likierów i koniaku Kapps Ltd (ul. Peretz 3), przekonując: „Wódka krzepi - Kappsa lepiej”58. Salon odzieżowy J. Shapira (Allenby Road 67) oferował ,najnowsze modele płaszczy, kostiumów, ubrań i palt - dla pań, panów i dzieci" 59 . Komitet Uchodźców Polskich w Tel Awiwie organizował klub sportowy „z następującymi sekcjami: 1) pływacka i wioślarska, 2) piłkarska, lekkoatletyczna i gier sportowych, 3) tenisowa i bokserska, 4) wycieczkowa"60.

Uwaga uchodźców nie koncentrowała się wyłącznie na sprawach polskich, ale ich życie w dużym stopniu toczyło się w obrębie polskiej wspólnoty. Zapewniała ona zaspokojenie różnych potrzeb, starając się stworzyć pozory normalnego życia. Była również

\footnotetext{
${ }^{53}$ Archiwum Katedry Polowej Wojska Polskiego w Warszawie (dalej: AKP), Du III/T. 263/2, „Sprawozdanie z działalności Katolickiego Duszpasterstwa Polskiego w Palestynie za rok 1944”, k. 4-5.

${ }^{54}$ Zachowało się 59 grobów, na terenie kwatery pochowano także kilku uchodźców, których mogiły nie przetrwały. A. Patek, Polski cmentarz w Jafie. Z dziejów Polonii w Izraelu, Kraków 2016, s. 83-84, $195-198$.

${ }^{55}$ Przedstawienie było grane ponad dwadzieścia razy (także poza Tel Awiwem). GP, 6 XI 1941, s. 1.

${ }^{56}$ Relacja aktora Gwidona Boruckiego (1912-2009) zanotowana przez Annę Mieszkowską w: Hanka Ordonówna. Miłość jej wszystko wybaczy, Warszawa 2019, s. 192.

${ }^{57}$ L. Lawiński, ,Aczkolwiek”. Opowiadania z 1000-ca i jednej nocy, Londyn 1963, s. 74. Bracia Jędrzejewicze - Janusz (były premier) i Wacław (późniejszy prezes Instytutu Józefa Piłsudskiego w Ameryce).

${ }^{58}$ GP, 17 XII 1943, s. 2; także: A. Klugman, Polonica w Ziemi Świętej, Kraków 1994, s. 66.

${ }^{59}$ GP, 28 III 1943, s. 4.

${ }^{60}$ GP, 19 V 1943, s. 4.
} 
druga strona tego zjawiska. Jak przyznają współczesne raporty, Polacy (wyjąwszy indywidualne przypadki) trzymali się razem, nie integrując się z miejscową społecznością. Skądinąd można to zrozumieć, biorąc pod uwagę istniejące różnice kulturowe i w sferze mentalności ${ }^{61}$.

W wir życia polskiego włączyło się wielu wygnańców pochodzenia żydowskiego. Część uważała się po prostu za Polaków. Wchodzili w skład uchodźczych organizacji, pracowali w redakcjach gazet, wypełniali sale odczytowe. Mieli swój udział w stworzeniu tutaj „kawałka Polski”. Inni od początku utrzymywali kontakty głównie z miejscową ludnością żydowską wywodzącą się z Polski, nie angażując się w sprawy uchodźcze ${ }^{62}$.

\section{Oblicze polityczne}

Ponieważ polityka była siłą sprawczą emigracji wojennej, stanowiła dla uchodźców ważny punkt odniesienia. Zdecydowana większość opowiadała się po stronie rządu na obczyźnie. Problem w tym, że po cofnięciu uznania temu rządowi przez zachodnie mocarstwa (5 lipca 1945 r.), przestał on być realną siłą polityczną. O skali poparcia dla polskich władz w Londynie możemy wnosić na podstawie akcji zorganizowanej podczas wypłaty zasiłku wrześniowego w 1945 r. Chodziło o złożenie podpisu pod wspólną odezwą Komitetu Porozumiewawczego Organizacji Polskich w Tel Awiwie oraz tamtejszego KUP do brytyjskiej Labour Party, która z końcem lipca, po wieloletnich rządach konserwatystów, przejęła władzę w Wielkiej Brytanii.

Odezwa ta była dramatycznym apelem o uznanie praw narodu polskiego „do demokratycznego rządzenia się i do suwerennego bytu"63. Podpis pod nią złożyło 2543 uchodźców, ,za” opowiedziały się 2292 osoby (tj. 90\%), przeciw było 48, a wstrzymało się 203 uchodźców ${ }^{64}$. Nawet jeśli uwzględnimy, że „w większości przypadków głowa rodziny podpisywała się za całą rodzinę" że pozbawić prawa do zasiłku, przekonania polityczne większości emigrantów nie budziły wątpliwości ${ }^{66}$.

Dowodziła tego inna odezwa, wystosowana 10 lipca 1945 r. przez zwierzchników polskiej emigracji w Palestynie. Ogłoszono ją więc zaraz po uznaniu przez Wielką Brytanię władz w Warszawie. Uwagę zwracał wyróżniony dużą czcionką fragment: ,prawdziwym przedsta-

${ }^{61}$ IPMS, A 9 VII/8, Sprawozdanie Referatu Narodowościowego, k. 18.

${ }^{62}$ BJ, ADP, sygn. 11855 IV, Sprawozdanie T. Malickiego, k. 86-87.

${ }^{63}$ IPMS, Kol. 660/4, „Apel do Partii Pracy w Wielkiej Brytanii”, Tel Awiw, wrzesień 1945 r.

${ }^{64}$ Dla porównania w Jerozolimie na 2127 uprawnionych głos ,za” oddało 1832 uchodźców (40 było przeciw, a 255 wstrzymało się), w Rechowot - 496 (na 504 uprawnionych), w Hajfie - 187 (na 232 uprawnionych). W Jerozolimie akcję zorganizowano przy wypłacie zasiłku sierpniowego, a podpisy składano pod odezwą przedstawicieli władz i urzędów polskich w Palestynie, wystosowaną po cofnięciu uznania rządowi na uchodźstwie. Inicjatorem zbierania podpisów był Centralny Komitet Uchodźców Polskich w Palestynie. BJ, ADP, sygn. 11855 IV, Sprawozdanie T. Malickiego, k. 92.

${ }^{65}$ Ibidem.

${ }^{66}$ Brytyjczycy szacowali, że wiernych rządowi londyńskiemu było 98\% polskich uchodźców w Palestynie. UNA, UNRRA, S-1021-0151-13, „Notes concerning the support of Polish refugees in Palestine”, brak daty (prawdopodobnie koniec 1945 r.); BPOSK, Rps 1279, Papiery S. Rosmańskiego, dok. 10: „Notatka”, brak daty (druga połowa 1945 r.), k. 3; tu mowa o poparciu rzędu $90 \%$. 
wicielstwem państwa i narodu polskiego jest konstytucyjny Prezydent i legalny Rząd Polski w Londynie" ${ }^{97}$. Wśród sygnatariuszy z Tel Awiwu byli m.in. Konsul Generalny RP Henryk Rosmarin oraz Komitet Porozumiewawczy Organizacji Polskich. Pod odezwą odręczne podpisy złożyli polscy uchodźcy z Tel Awiwu i innych ośrodków w Palestynie. Program polityczny był prosty i zakładał: (1) przywrócenie Polsce niepodległości oraz (2) uznanie „komitetu lubelskiego" za władzę uzurpatorska, narzuconą przez Sowiety. W dołączonej deklaracji wyrażano wolę, by przedstawiciele rządu RP w Londynie sprawowali dalszą moralną i materialną opiekę nad uchodźcami i reprezentowali ich wobec miejscowych władz ${ }^{68}$.

Formowało się przekonanie, że to właśnie emigracja reprezentuje tradycje suwerennej Rzeczypospolitej. Uchodźcy wojenni po zakończeniu wojny wciąż nimi pozostawali, ale coraz częściej używano określenia: „emigracja niepodległościowa”. Kształtował się swoisty kodeks zachowania. Z osobami lojalnymi wobec władz w Warszawie nie utrzymywało się kontaktów towarzyskich, nie zapraszało do stolika. Ci, którzy złamali te niepisane zasady, musieli liczyć się z bojkotem ${ }^{69}$.

Jednym z nich był Jerzy Lechowski, kierownik Ekspozytury Delegatury MPiOS w Tel Awiwie. Gdy w październiku 1947 r., już po zwinięciu ekspozytury i formalnym zdaniu urzędu, rozeszły się pogłoski, że Lechowski zamierza wyjechać do Polski i kontaktuje się $\mathrm{w}$ tej sprawie z przedstawicielami władz w Warszawie, spotkało się to z bardzo emocjonalnymi komentarzami, w których nie szczędzono byłemu kierownikowi grubych słów (,zdrada, odstępstwo" etc. ${ }^{70}$. Kilka dni przed terminem planowanego wyjazdu Lechowski doznał udaru mózgu i zmarł. Pochowano go w polskiej kwaterze cmentarza katolickiego w Jerozolimie na górze Syjon. Ostracyzm dotknął Lechowskiego nawet po śmierci, ponieważ na jego pogrzeb nie przybył nikt z Rady Naczelnej Uchodźstwa Polskiego, ani z obydwu Komitetów Uchodźców: w Jerozolimie i Tel Awiwie ${ }^{71}$.

Popieranie polskich władz w Londynie w wielu przypadkach było koniecznością. Decydowała o tym własna biografia. Na przykład uchodźcy z Kresów Wschodnich nie mogli powrócić do stron rodzinnych, gdyż zajął je ZSRR. Nie potrafili zapomnieć lat spędzonych na zesłaniu. Na decyzję o pozostaniu na uchodźstwie miała wpływ służba pod rozkazami gen. Andersa, którego nowe władze w Warszawie uznały za politycznego przeciwnika.

To, że w sprawach pryncypialnych mówiono jednym (lub prawie jednym) głosem, nie oznaczało, że emigranci byli jednomyślni w innych kwestiach. Mimo szczupłych rozmiarów tego środowiska, istniały głębokie podziały polityczne. Ostry konflikt dzielił ludzi związanych z przedwojennym ośrodkiem władzy (piłsudczycy, sanacja) i zwolenników nowego rządu (gen. Władysława Sikorskiego). Prowadziło to do snucia intryg i rozgrywek, a na tym traciła tylko spoistość uchodźstwa i jego potencjał.

${ }^{67}$ AAN, Akta Antoniego Pająka, sygn. 19, „Do Uchodźctwa Polskiego w Palestynie”, k. 2 (niedatowany maszynopis); także w: IPMS, Kolekcja 660/4 (jako druk, podana data).

${ }^{68}$ Ibidem, k. 2-4.

${ }^{69}$ Archiwum Instytutu Pamięci Narodowej w Warszawie (dalej: AIPN) BU 1419/88, Teczka obiektowa krypt. „Reduta”/ „Upadli”, k. 100, Raport pt. „Prasa i propaganda reakcyjna” (niedatowany).

${ }^{70}$ Po cofnięciu uznania rządowi RP w Londynie placówka działała jako Ekspozytura Delegatury Polskiej Opieki. IPMS, Kol. 551, materiały biobibliograficzne dotyczące J. Lechowskiego, k. 4.

${ }^{71} \mathrm{~W}$ pogrzebie wzięli udział m.in. urzędnicy Delegatury Polskiej Opieki oraz (co ciekawe) przedstawiciel władz warszawskich, Konsul Generalny w Jerozolimie Olgierd Górka. IPMS, A 11E/1230, Wyciąg z listu konsula Stanisława Rosmańskiego, Tel Awiw 25 XI 1947 r. 
Formalnie działało kilka stronnictw politycznych, ale odcięte od zaplecza w Kraju i dopływu członków szybko przekonały się, jak trudno jest skutecznie funkcjonować w nowych warunkach. Większość miała charakter kanapowy, a znaczenie zawdzięczały indywidualnościom swoich prezesów. W Tel Awiwie najbardziej liczyli się piłsudczycy, którzy w 1944 r. zorganizowali się w grupę pod nazwą Związek Pracy dla Państwa. W latach wojny ukształtował się w Palestynie ważny ośrodek politycznej aktywności tego środowiska $^{72}$. Stało się tak, ponieważ po upadku Polski we wrześniu 1939 r. wielu polityków i wojskowych związanych z sanacją ewakuowało się do Rumunii, skąd potem dotarli na Bliski Wschód. Znaleźli się wśród nich ministrowie ostatniego gabinetu II RP, posłowie i senatorowie, urzędnicy, oficerowie i in. ${ }^{73}$ Przedstawiciele innych obozów politycznych nie mieli takich możliwości i jedynie niektórym udało się przejść później przez granicę.

W Tel Awiwie swoją bazę miały również środowiska komunistyczne. Koncentrowały się wokół powstałego w 1944 r. Związku Patriotów Polskich na Środkowym Wschodzie $(Z P P)^{74}$. Grupy te były bardzo hałaśliwe, działały pod różnymi szyldami, co miało stwarzać pozory wpływów wśród emigracji, a w rzeczywistości służyło jej destabilizacji. Nie zdobyły większego poparcia ${ }^{75}$, ale ich rola wzrosła po uznaniu przez Wielką Brytanię władz w Warszawie w lipcu 1945 r.

Osobliwością życia politycznego było to, że ton nadawały mu bynajmniej nie partie, ale organizacje i stowarzyszenia formalnie apartyjne (związki byłych żołnierzy, zrzeszenia zawodowe, naukowe etc.), jakkolwiek nie apolityczne w znaczeniu działalności niepodległościowej. W odróżnieniu od kanapowych partii mogły uchodzić wręcz za masowe, skupiając w swych szeregach (w całej Palestynie) od kilkudziesięciu do nawet kilkuset członków ${ }^{76}$.

\section{Problemy}

Rada Naczelna Uchodźstwa Polskiego w Palestynie ${ }^{77}$ szacowała, że pod koniec 1947 r., po ewakuacji do Wielkiej Brytanii rodzin wojskowych, w Ziemi Świętej pozostało w przybliżeniu 1100 polskich emigrantów wojennych. Wśród nich było: ,a) poważnie chorych

\footnotetext{
${ }^{72}$ A. Bieńkowska, Działalność Zwiazku Pracy dla Państwa na Bliskim Wschodzie w czasie drugiej wojny światowej, „Archiwum Emigracji. Studia. Szkice. Dokumenty” 2009, z. 1 (10), s. 73-90; M. Sioma, Pitsudczycy w Palestynie 1940-1945, [w:] Polska bez Marszałka. Dylematy piłsudczyków po 1935 roku. Zbiór studiów, red. M. Wołos, K. Kania, Toruń 2008, s. 125-149.

${ }^{73} \mathrm{~W}$ Tel Awiwie przebywali m.in. byli premierzy Sławoj Składkowski i Janusz Jędrzejewicz, Wiktor Tomir Drymmer (dyrektor Departamentu Konsularnego MSZ), gen. Jakub Krzemieński (przed wojną prezes Najwyższej Izby Kontroli), wicemarszałek Senatu Stefan Dąbkowski. W.T. Drymmer, W stużbie Polsce. Wspomnienia żotnierza i państwowca z lat 1914-1947, Kraków 2014, s. 354.

${ }^{74}$ J. Pietrzak, Działalność komunistów wśród polskiego wychodźstwa na Bliskim Wschodzie w świetle materiałów kontrwywiadu Polskich Sit Zbrojnych (1944 r.), „Dzieje Najnowsze” 2006, nr 3, s. 119-136; H. Zatorska, Spoza smugi cienia. Wspomnień ciag dalszy, Kraków-Wrocław 1985, rozdz. 4 (subiektywne wspomnienia działaczki ZPP).

${ }^{75}$ Jesienią 1945 r. liczbę zwolenników tych grup w całej Palestynie szacowano na około 300 osób. BJ, ADP, sygn. 11855 IV, Sprawozdanie T. Malickiego, k. 94-95.

${ }^{76}$ IPMS, Kol. 660/4, Pismo Prezydium Rady Naczelnej Uchodźstwa Polskiego w Palestynie do Rady Polskich Ugrupowań Politycznych w Londynie, Jerozolima 23 III 1946 r.

${ }^{77}$ Rada wyrażała wierność Rządowi RP na Uchodźstwie. Działała w latach 1945-1948. IPMS, A 76/1, Statut Rady Naczelnej Uchodźstwa Polskiego w Palestynie.
} 
na gruźlicę około 5\%, b) shyzofroników i neurasteników około $10 \%$, c) alkoholików i weneryków około 10\%, d) osób zaliczonych do przestępców (złodziei, oszustów, typów zbrodniczych itp. karanych w Kraju lub Palestynie) - około 5\%" ${ }^{78}$. Duży odsetek stanowiły osoby po pięćdziesiątym roku życia, zwolnieni ze służby wojskowej na skutek złego stanu zdrowia lub nabytego kalectwa, wdowy po poległych i zaginionych żołnierzach, samotne kobiety z dziećmi oraz sieroty. Zaledwie co piąty uchodźca był zdolny do pracy fizycznej, ale głównie takiej, która nie wymagała większego wysiłku. Pozostali potrzebowali właściwie stałej opieki ${ }^{79}$.

Nie wiemy, jak konkretnie te sprawy wyglądały w Tel Awiwie, ale można sądzić, że i tam występowały podobne problemy. Przemawia za tym kilka przesłanek. Znacząca część uchodźców, którzy osiedlili się w mieście w 1942 r. i później, to dawni więźniowie sowieckich łagrów. Niedożywienie i praca ponad siły w obozach i na zesłaniu były przyczyną wyczerpania, chorób oraz przedwczesnych zgonów. Na kondycję emigrantów wpływały również właściwości klimatu w Palestynie. Upalne i bezdeszczowe lata zwiększały ryzyko udaru słonecznego oraz odwodnienia organizmu, co prowadziło do utraty sił, a nawet zagrażało życiu. Większość Polaków, których zgon odnotowała „Liber defunctorum” miejscowej parafii rzymskokatolickiej w Jafie, zmarła nie ukończywszy 50 lat (52 osoby na 64), w tym 18 odeszło zaraz po urodzeniu albo w dzieciństwie (zob. tab. 5) ${ }^{80}$.

Tab. 5. Polscy uchodźcy pochowani na cmentarzu katolickim w Jafie według długości życia $^{81}$

Wiek

Zmarli w dzieciństwie

19-30 lat

31-50 lat

51-70 lat

powyżej 70 lat
Liczba pochowanych

18

8

26

8

4

Jak można wnosić z dokumentacji Katolickiego Duszpasterstwa Polskiego w Palestynie, częstą przyczyną śmierci były zapalenie płuc, gruźlica i udar serca. Niektórzy uchodźcy umierali z powodu wycieńczenia organizmu, duru brzusznego. Zdarzały się także odejścia w tragicznych okolicznościach (samobójstwo, utonięcie, morderstwo) ${ }^{82}$.

Poważną bolączką były sprawy materialne. Wprawdzie działania wojenne ominęły Palestynę, ale ich reperkusje dawały się we znaki. W kraju panowała drożyzna, rosły koszty utrzymania. Wysokość zasiłków nie zaspokajała wszystkich potrzeb. Zdarzało się, że

${ }^{78}$ IPMS, A 76/26, Pismo Rady Naczelnej Uchodźstwa Polskiego w Palestynie do Zjednoczenia Polskiego Uchodźstwa Wojennego z siedzibą w Brukseli, Jerozolima, 2 XII 1947 r.

${ }^{79}$ Ibidem.

${ }^{80}$ Dane za lata 1941-1948. Archiwum Polskiej Misji Katolickiej w Anglii i Walii, Londyn, zesp. Ordynariat Polowy bp. J. Gawliny, dokumenty Katolickiego Duszpasterstwa Polskiego w Palestynie; A. Patek, Polski cmentarz w Jafie, s. 78, 198.

${ }^{81}$ Ibidem.

${ }^{82}$ Ibidem. W sierpniu 1943 r. wśród uchodźców w Tel Awiwie „wybuchła epidemia tyfusu brzusznego”. Źródłem zachorowania miała być ,stołówka, prowadzona przez Komitet Uchodźców”. IPMS, PRM.L.67, Sprawozdanie Delegata PCK na Palestynę Andrzeja Jenicza, 27 IX 1943 r., k. 3. 
oszczędzano nawet na jedzeniu ${ }^{83}$. Jak donosił zorientowany w miejscowych realiach „Kurjerek Codzienny”, bywało, że uchodźcy już „na drugi dzień po wypłacie [zasiłków] są dosłownie bez grosza"84. Sytuacja pogorszyła się w 1947 r., kiedy IRO dwukrotnie w ciągu kilku miesięcy obcięła dotacje na zasiłki uchodźcze (wysokość świadczeń zredukowano łącznie o $11 \%$, z 11 do 9,75 funtów palestyńskich miesięcznie) $)^{85}$.

Przeżycia wojenne oraz przedłużający się pobyt na uchodźstwie negatywnie wpływały na wrażliwość etyczną. Część Polaków świadomie wolała utrzymywać się z niewielkiego (ale stałego) zasiłku, ponieważ nie chcieli wykonywać pracy fizycznej poniżej swoich kwalifikacji ${ }^{86}$. O pracę w ówczesnej Palestynie nie było zresztą łatwo. Z upływem lat spadało zainteresowanie działalnością społeczną i kulturalną. Jak donosiło Katolickie Duszpasterstwo Polskie, nie wszyscy potrafili oprzeć się pokusom życia, co prowadziło do upadku obyczajów (rozwiązłość, pijaństwo itp.) ${ }^{87}$. Niektórzy (byli wśród nich współobywatele pochodzenia żydowskiego) znajdowali zatrudnienie np. w kibucach, a równocześnie ,tak formalnie się urządzali, aby nie mogło to mieć wpływu na zasiłki otrzymywane z funduszów polskich"s8.

Brak aktywności zawodowej ${ }^{89}$ sprzyjał swarom, intrygom i walkom o stołki. „Z biegiem czasu już niemal każdy z uchodźców udowadniał, jak wielką był figurą w Polsce, a gdy każdego roku należało zmieniać składy komitetów, zarządów, dyrekcji i prezydiów, garnitury zmieniały się w pełnym komplecie" ${ }^{90}$. Powstawały kliki i koterie różnych odcieni.

Trafiali się awanturnicy i poszukiwacze łatwego zarobku, zdemoralizowani wojną i pobytem w łagrach. Miejscowa prasa donosiła o polskich uchodźcach, którzy popadli w konflikt z prawem. „W związku z rosnącą w całym kraju liczbą kradzieży, policja w Tel Awiwie, działając na podstawie przepisów nadzwyczajnych, zatrzymała 20 notowanych już wcześniej polskich uchodźców" - informował w sierpniu 1944 r. żydowski anglojęzyczny dziennik „The Palestine Post”91. Kilka miesięcy wcześniej (w styczniu) policja w Tel Awiwie aresztowała 38 uchodźców pod zarzutem rabunku i kradzieży. Wśród zatrzymanych byli m.in. zwolnieni z wojska ${ }^{92}$.

${ }^{83}$ Niektórzy oszczędzali „nie jadając obiadów, a żyjąc chlebem, pomidorami i pomarańczami”. Cyt. za: Budżet samotnego uchodźcy, „Kurjerek Codzienny” (Tel Awiw), 25 IV 1941, s. 6.

${ }^{84}$ Ibidem.

${ }^{85}$ NA, FO 371/71354, Pismo Edwarda Raczyńskiego do P.F. Hancocka z FO, 19 II 1948 r.; IPMS, A 76/26, Memoriał przedłożony przez Radę Naczelną Uchodźstwa Polskiego i Komitety Uchodźców w Tel Awiwie i Jerozolimie przedstawicielowi IRO, Jerozolima, 6 X 1947 r., k. 2.

${ }^{86}$ Jak czytamy w instrukcji Delegatury MPiOS, do zasiłku miały „zasadniczo prawo jedynie osoby nie mające pracy”. Uchodźcy „,posiadający uboczne zarobki, przekraczające ustalone [...] maksimum”, tracili częściowo lub w całości prawo do zasiłku. IPMS, A 49/21, „Wyciąg z instrukcji Del. M.P.iO.S. - przepisy i zarządzenia dot. uchodźców", 22 VIII 1943 r.

${ }^{87}$ AKP, Du III/T. 263/2, ,Sprawozdanie z działalności Katolickiego Duszpasterstwa Polskiego w Palestynie za rok 1944", k. 7-9.

${ }^{88}$ BJ, ADP, sygn. 11855 IV, Sprawozdanie T. Malickiego, k. 87.

${ }^{89}$ Według UNRRA, w grudniu 1945 r. w Palestynie pracowało 360 polskich uchodźców, którzy nie pobierali zasiłku. UNA, UNRRA, S-1021-0151-13, „Information on Polish refugees in Palestine”, s. 1-2.

${ }^{90}$ IPMS, A 9 VII/8, Sprawozdanie Referatu Narodowościowego, k. 22.

${ }^{91}$ Notatka w numerze z dnia 29 VIII 1944 r. (s. 3).

${ }^{92}$ AAN, MPiOS 94, Sprawozdanie Ekspozytury Delegata MPiOS w Tel Awiwie za styczeń 1944 r., Jerozolima 20 III 1944, k. 137; Prison for three soldiers, „The Palestine Post”, 24 II 1944, s. 3. Także wcześniejszy artykuł: Three Polish soldiers to prison for robbery, ibidem, 1 IV 1943, s. 3. 
Zdarzały się zgrzyty w stosunkach polsko-żydowskich, chociaż układały się one na ogół poprawnie. Czasem chodziło o drobnostki, jak sprzeczki o przysłowiowy stolik kawiarniany czy miejsce w autobusie. Dochodziło jednak i do poważniejszych incydentów. Tak było w listopadzie 1942 r., gdy bójka między żołnierzami uczniami polskiego liceum w Tel Awiwie a młodzieżą z pobliskiej żydowskiej szkoły technicznej doprowadziła do zamieszek. Budynek liceum obrzucono kamieniami, kilku wyrostków próbowało wtargnąć do środka. Na ulicy zgromadził się tłum. Interweniowała polska żandarmeria i brytyjska policja. Nerwowe nastroje udało się opanować dopiero po kilku dniach, z pomocą Agencji Żydowskiej i Histadrutu' ${ }^{93}$

Incydent wzbudził emocje po obydwu stronach, co świadczyło o dużym uwrażliwieniu w kontekście stosunków polsko-żydowskich. Być może właśnie to uwrażliwienie sprawiło, że wspomniana bójka między uczniami szkoły polskiej i żydowskiej wykroczyła poza ramy żakowskiej bijatyki. Na delikatną naturę obustronnych relacji złożyło się wiele przyczyn: wzajemne urazy wyniesione jeszcze z Kraju, awantury wszczynane przez pijanych żołnierzy polskich, napięta sytuacja w Palestynie (konflikt arabsko-żydowski). Żydzi wskazywali na zachowania antysemickie w 2. Korpusie gen. Andersa. Z kolei Polacy podnosili sprawę dezercji żołnierzy narodowości żydowskiej, zarzucając im nielojalność. Przybycie jednostek polskiego wojska do Palestyny stworzyło warunki do dezercji, bo Żydzi poczuli się w swoim kraju i chcieli włączyć się w jego rozwój. Przyszłość wiązali z Palestyną, gdyż ich bliscy stracili życie w Holokauście. W tej sytuacji wierność polskiemu mundurowi ustępowała lojalności wobec Erec Israe ${ }^{94}$.

Zbiorowym doświadczeniem uchodźców było uczucie niepewności. Nasiliło się, gdy władze brytyjskie cofnęły uznanie rządowi na obczyźnie. Kto teraz będzie reprezentował nasze interesy?, co dalej z zasiłkami?, w jaki sposób przeciwstawić się infiltracji ze strony przedstawicieli władz w Warszawie, którzy grali na podsycanie wewnętrznych konfliktów w środowisku emigracji ${ }^{95}$

Sytuacja skomplikowała się jeszcze bardziej pod koniec 1947 r., gdy w Palestynie wybuchła arabsko-żydowska wojna domowa. Polscy mieszkańcy Tel Awiwu i sąsiedniej Jafy znaleźli się na styku wrogich obozów. Oba miasta dzieliła linia frontowa, opuszczony przez ludzi pas zabudowań. Jak informował gen. Józef Wiatr, dowódca Jednostek Wojska na Środkowym Wschodzie, ludność polska, kontaktując się ze sobą, przekraczała ,ten «pas

${ }^{93}$ IPMS, A 20.4a/125, „Akta w sprawie zajść polsko-żydowskich w Tel-Avivie” (listopad 1942 r.). O przebiegu konfliktu informował Delegat MPiOS T. Lubaczewski w listach do ministra S. Kota: BJ, Papiery Stanisława Kota, Przyb. 120/83, pisma z 6, 7 i 8 XI 1942 r.; AAN, MPiOS 94, k. 327-328. Wśród przyczyn zajść wskazywano m.in. prowokację komunistyczną, nastroje antysemickie w wojsku polskim, a nawet inspirację ze strony środowisk rządowych (kierowniczką szkoły była kojarzona z piłsudczykami Helena Baryszowa, a jednym z wykładowców przedwojenny premier J. Jędrzejewicz). Ibidem; W.T. Drymmer, W stużbie Polsce, s. 353; A. Patek, Komisja Badawcza Ministerstwa Sprawiedliwości Rzqdu RP o zajściach w Tel Awiwie w listopadzie 1942 roku, [w:] Europa Środkowa i Bałkany. Konteksty historyczne i politologiczne. Narody, mniejszości narodowe i religijne. Księga Jubileuszowa ofiarowana prof. dr hab. Irenie Stawowy-Kawce, red. M. Korzeniewska-Wiszniewska, A. Kastory, R. Woźnica, Kraków 2019, s. 359-367.

${ }_{94}$ Do marca 1944 r. liczba dezerterów wynosiła 2972 osoby. Szerzej zob. T. Gąsowski, Pod sztandarami Orła Biatego. Kwestia żydowska w Polskich Siłach Zbrojnych w czasie II wojny światowej, Kraków 2002, s. 146-176; tamże dalsza bibliografia.

${ }^{95}$ Latem 1945 r. otworzył swoje biuro w Tel Awiwie Delegat Tymczasowego Rządu Jedności Narodowej, a jesienią uruchomiono podległy Warszawie konsulat. B. Szaynok, Z historiq i Moskwq w tle. Polska a Izrael 1944-1968, Warszawa 2007, s. 57. 
neutralny», strzeżony z obu stron przez uzbrojone oddziały, [i była] podejrzewana, że prowadzi wywiad dla jednej lub drugiej strony"96. Przemieszczanie się Polaków między strefami arabskimi i żydowskimi było właściwie nie do uniknięcia. O ile w Tel Awiwie mieściła się większość cywilnych placówek uchodźczych, to miejsca ważne dla życia duchowego (parafia) znajdowały się w Jafie, zamieszkałej przeważnie przez Arabów.

Rozchodziły się pogłoski, że zdemobilizowani żołnierze mieli szkolić oddziały arabskie, a nawet walczyć po ich stronie ${ }^{97}$. Nieufność panowała również w środowiskach arabskich, na przykład w Jafie zdarzało się, że rewidowano Polaków przy przechodzeniu z dzielnic arabskich do żydowskich, podejrzewając ich o współpracę z Żydami. W Jafie kilku polskich uchodźców zostało poturbowanych przez grupy Arabów ${ }^{98}$.

W noc sylwestrową $1947 \mathrm{r}$. zdemolowano położone po sąsiedzku (w tym samym budynku w Tel Awiwie) lokale Towarzystwa Pomocy Polakom oraz Koła Pań Pracujących Społecznie ${ }^{99}$. Niecałe dwa tygodnie później (12 stycznia 1948 r.) zostały zajęte pomieszczenia tamtejszej Kaplicy Polskiej ${ }^{100}$. Zamieszkała w nich bezdomna ludność żydowska z pogranicza Jafy i Tel Awiwu. Jak się wydaje, u podłoża tych wypadków nie leżały nastroje antypolskie, gdyż w tym czasie uciekinierzy z zagrożonych dzielnic przejmowali również synagogi ${ }^{101}$.

Na wytworzenie się tej sytuacji wpłynęły różne czynniki: (1) rozmieszczenie ludności polskiej, która koncentrowała się zarówno w ośrodkach żydowskich (Tel Awiw, Rechowot), jak i arabskich (Jafa, wschodnia Jerozolima); to poruszanie się między wrogimi obozami budziło podejrzenia obydwu stron ${ }^{102}$; (2) właściwa każdej wojnie atmosfera podejrzliwości; (3) działalność agentów władz warszawskich, które twierdziły, że emigracja polska jest „faszystowska” i wysługuje się imperialistom brytyjskim ${ }^{103}$; (4) obecność wśród wygnańców środowisk przestępczych i ludzi z marginesu. Wprawdzie jednostki patologiczne stanowiły niewielki procent, to jednak ich poczynania bardzo negatywnie odbijały się na wizerunku Polaków. Jak przyznawał gen. Wiatr, ludzie ci trudnili się przemytem „,z ośrodków żydowskich do ośrodków arabskich, zarabiając w ten sposób dość poważne kwoty”. Dziennik „Haboker” (związany z środowiskiem Ogólnych Syjonistów) dodawał, że Polacy z szemraną przeszłością mieli przeprowadzać „,z bandami arabskimi napady na konwoje żydowskie, pociagi i magazyny"104.

${ }^{96}$ IPMS, A VIII 3/3, Pismo gen. J. Wiatra do gen. W. Andersa, 15 I 1948 r., k. 1.

${ }^{97}$ F. Offner, Syrian ,war” was no secret, ,The Palestine Post”, 11 I 1948, s. 4.

${ }^{98}$ BPOSK, 1608, Sytuacja Polaków w Palestynie, „Sprawy Bliskiego i Środkowego Wschodu”, no 4, 16 I 1948, s. 2. Sprawy te prezentujemy zwięźle, ponieważ szerzej przedstawiono je w: A. Patek, Polska emigracja niepodległościowa $w$ Tel Awiwie po drugiej wojnie światowej (1945-1948), „Studia Środkowoeuropejskie i Bałkanistyczne", t. XXIV, Kraków 2016, s. 112-114.

${ }^{99}$ BPOSK, Rps 1279, Papiery S. Rosmańskiego, dok. 35: Pismo S. Rosmańskiego do A. Pająka, 9 I 1947 r.; ibidem, dok. 44: „Sytuacja w Palestynie na dzień 5 stycznia 1948 r.”; IPMS, A VIII 3/3, Pismo gen. J. Wiatra do gen. W. Andersa, 15 I 1948 r., k. 2.

${ }^{100}$ BPOSK, Rps 1279, Papiery S. Rosmańskiego, dok. 24: Pismo S. Rosmańskiego do A. Pająka, 12 I $1948 \mathrm{r}$.

${ }^{101}$ BPOSK, Rps 1279, Papiery S. Rosmańskiego, dok. 24.

${ }^{102}$ BPOSK, 1608, Sytuacja Polaków w Palestynie, s. 2.

${ }^{103}$ Stwierdzenia takie znalazły się w piśmie Konsulatu Generalnego RP w Jerozolimie (podległego władzom w Warszawie). Archiwum Ministerstwa Spraw Zagranicznych w Warszawie, zespół 21/49/697, „Wytyczne do oceny sytuacji politycznej w Palestynie", 16 I 1948 r.

${ }^{104}$ IPMS, A VIII 3/3, Pismo gen. J. Wiatra do gen. W. Andersa, k. 1-2. 


\section{Zakończenie}

Tel Awiw był miastem ważnym nie tylko dla żydowskich emigrantów z Polski, ale również dla polskich uchodźców wojennych. W egzotycznej scenerii Polakom udało się zbudować namiastkę Ojczyzny na obczyźnie. Przy całej różnorodności wygnańcy tworzyli pewną mikrospołeczność, która odróżniała się od miejscowego społeczeństwa. Zbiorowość ta żyła swoim życiem, miała własne troski i radości. Miała również wyraźną specyfikę - duży odsetek ludzi chorych i samotnych wymagających opieki, wysoki współczynnik feminizacji, nietypową strukturę społeczno-zawodową (znaczący udział inteligencji i osób wykonujących wolne zawody), zróżnicowany skład narodowościowy i wyznaniowy.

Zdecydowana większość uchodźców deklarowała przywiązanie do wartości narodowych, opowiadała się za niepodległą Polską. Mimo szczupłych rozmiarów rozwinęli bogatą aktywność społeczną i kulturalną. Z drugiej strony nie uchronili się od zjawisk negatywnych - trapiły ich podziały polityczne, wewnętrzne swary i intrygi. Przedłużający się pobyt na uchodźstwie i brak perspektyw na szybki powrót do Kraju rodziły frustrację. U części osób przeżycia wojenne negatywnie odbiły się na ich poziomie etycznym i moralnym. Niektórzy wchodzili w konflikt z prawem, notowano zachowania o charakterze patologicznym.

W losach telawiwskich Polaków niczym w soczewce skupiały się problemy wychodźstwa niepodległościowego: (1) zainteresowanie polityką wypełniało treść życia; (2) coraz większą troskę budziły sprawy bytowe - zasiłki wystarczały, by nie umrzeć z głodu, ale nie pozwalały godnie żyć; (3) świadomość braku jakiegokolwiek wpływu na zmianę sytuacji politycznej w ojczyźnie.

Interesujące byłoby pokazanie, jak ułożyły się drogi życiowe uchodźców po wyjeździe z Tel Awiwu. Zarówno tych, którzy wrócili do kraju, jak i tych, którzy pozostali na emigracji. Wątek ten zasługuje na osobną uwagę i bez wątpienia stanowiłby ciekawe uzupełnienie portretu zbiorowego analizowanej społeczności.

\section{Bibliografia}

Materiały archiwalne

1) Instytut Polski i Muzeum im. gen. Sikorskiego w Londynie

Armia Polska na Wschodzie - A VIII 3/3

Delegatura Ministerstwa Wyznań Religijnych i Oświecenia Publicznego - A 74/39

Kolekcja Władysława Andersa - KGA 11/398

Kolekcja Czesława Horaina - Kol. 551

Kolekcja Stanisława Kota - Kol. 25/23A

Kolekcja Stanisława Olszewskiego - Kol. 660/4, 660/6

Konsulat Generalny RP w Tel Awiwie - A 49/21, A 49/90

Ministerstwo Spraw Wewnętrznych - A 9 VII/8

Ministerstwo Sprawiedliwości - A 20.4a/125

Ministerstwo Spraw Zagranicznych - A 11 E/1230

Prezydium Rady Ministrów. Archiwum Liebermanowej - PRM.L. 67

Rada Naczelna Uchodźstwa Polskiego w Palestynie - A 76/1, A 76/26, A 76/48 
2) Biblioteka Polska POSK w Londynie

Papiery Stanisława Rosmańskiego, Rps 1279

3) The National Archives, London Foreign Office - FO 371/71354, FO 371/72083 Treasury - T 236/1387

4) Saint Anthony's Catholic Church, Tel Aviv-Jaffa „Defunctorum 06 May 1932 - 22 Sept. 2005”

5) United Nations Archives and Records Management Section, New York S-1021-0151-13 - UNRRA Displaced Persons Operation in Europe and Middle East

6) Archiwum Akt Nowych w Warszawie Akta Antoniego Pająka i jego rodziny - sygn. 19, 20 Ministerstwo Pracy i Opieki Społecznej - sygn. 94

7) Archiwum Instytutu Pamięci Narodowej w Warszawie Teczka obiektowa krypt. „Reduta”/ „Upadli” - BU 01419/88

8) Archiwum Katedry Polowej Wojska Polskiego w Warszawie Sprawozdania z działalności duszpasterskiej w Palestynie - Du III/T. 263/2

9) Biblioteka Jagiellońska w Krakowie Archiwum Domowe Pawlikowskich - sygn. 11855 IV

Papiery Stanisława Kota - Przyb. 120/83

Wspomnienia

Czuchnowski M., Cofnięty czas, Londyn 1945.

Drymmer W.T., W stużbie Polsce. Wspomnienia żotnierza i państwowca z lat 1914-1947, Kraków 2014.

Lawiński L., ,Aczkolwiek”. Opowiadania z 1000-ca i jednej nocy, Londyn 1963.

Zatorska H., Spoza smugi cienia. Wspomnień ciag dalszy, Kraków-Wrocław 1985.

Tytuły wykorzystanej prasy (współczesnej)

„Biuletyn Informacyjny Polskich Uchodźców Wojennych na Bliskim Wschodzie” (Jerozolima) 1941

„Gazeta Polska” (Jerozolima) 1941-1944

„Głos Polski” (Tel Awiw) 1942

„Ku Wolnej Polsce. Tygodnik Wojska Polskiego na Środkowym Wschodzie” (Kair) 1941

„Kurjerek Codzienny” (Tel Awiw) 1941

„Sprawy Bliskiego i Środkowego Wschodu” (Jerozolima) 1948

„The Palestine Post” (Jerusalem) 1941, 1943-1945, 1948

„Tygodnik Polski” (Nowy Jork) 1946

Monografie, rozprawy

Bieńkowska A., Działalność Zwiazku Pracy dla Państwa na Bliskim Wschodzie w czasie drugiej wojny światowej, „Archiwum Emigracji. Studia. Szkice. Dokumenty” 2009, z. 1 (10), s. 73-90.

Brown M.D., Stanowisko Foreign Office wobec rzqdów i komitetów na uchodźstwie w Wielkiej Brytanii podczas drugiej wojny światowej, [w:] Rzady bez ziemi. Struktury władzy na uchodźstwie, red. R.P. Żurawski vel Grajewski, Warszawa 2014, s. 303-320.

Brzoza C., Sowa A.L., Historia Polski 1918-1945, Kraków 2006.

Gąsowski T., Pod sztandarami Orła Białego. Kwestia żydowska w Polskich Siłach Zbrojnych w czasie II wojny światowej, Kraków 2002. 
Draus J., Oświata i nauka polska na Bliskim i Środkowym Wschodzie 1939-1950, Lublin 1993.

Draus J., Szkoły polskie w Tel-Awiwie 1940-1947, „Rocznik Komisji Nauk Pedagogicznych”, t. 39, Kraków 1987, s. 113-126.

Kantak K., Dzieje uchodźstwa polskiego w Libanie 1943-1950, Bejrut 1950.

Klugman A., Polonica w Ziemi Świętej, Kraków 1994.

Kondracki T., Jednostki Wojska na Środkowym Wschodzie 1944-1947, „Teki Historyczne”, T. 23, Londyn 2004, s. 230-253.

Łaptos J., Humanitaryzm i polityka. Pomoc UNRRA dla Polski i polskich uchodźców w latach 1944-1947, Kraków 2018.

Mieszkowska A., Hanka Ordonówna. Miłość jej wszystko wybaczy, Warszawa 2019.

Patek A., Polski cmentarz w Jafie. Z dziejów Polonii w Izraelu, Kraków 2016.

Patek A., Polska emigracja niepodległościowa w Tel Awiwie po drugiej wojnie światowej (1945-1948), „Studia Środkowoeuropejskie i Bałkanistyczne”, t. XXIV, Kraków 2016, s. 99-120.

Patek A., Polští váleční uprchlíci v Tel Avivu (1939-1948). Portrét prostředí, „Český časopis historický" (Praha), R. 117: 2019, č. 3, s. 613-636.

Pietrzak J., Działalność komunistów wśród polskiego wychodźstwa na Bliskim Wschodzie w świetle materiałów kontrwywiadu Polskich Sił Zbrojnych (1944 r.), „Dzieje Najnowsze” 2006, nr 3, s. 119-136.

Pietrzak J., Polscy uchodźcy na Bliskim Wschodzie w latach drugiej wojny światowej. Ośrodki. Instytucje. Organizacje, Łódź 2012.

Polskie Siły Zbrojne w drugiej wojnie światowej, vol. 2, Kampanie na obczyźnie, cz. 2, Londyn 1975.

Scanlon H.L., European Governments in Exile, Washington 1943.

Sioma M., Pitsudczycy w Palestynie 1940-1945, [w:] Polska bez Marszałka. Dylematy pitsudczyków po 1935 roku. Zbiór studiów, red. M. Wołos, K. Kania, Torun 2008, s. 125-149.

Szaynok B., Z historiq i Moskwa w tle. Polska a Izrael 1944-1968, Warszawa 2007.

Szulkin M., Żydzi palestyńscy w świetle raportów polskiej stużby dyplomatycznej, cz. II (1936-1939), „Biuletyn Żydowskiego Instytutu Historycznego” 1981, nr 1 (117), s. 63-82.

Tomaszewski J., Polski bank w Tel Awiwie, „Almanach Żydowski 1998-1999”, Warszawa [1998], s. 20-33.

Zakrzewski S., Czasy nadziei. Działalność oświatowo-polityczna w JWSW, Londyn 1972.

Żaroń P., Armia Andersa, Torun 2000.

Wydawnictwa o treści informacyjnej

Kowalik J., Bibliografia czasopism polskich wydanych poza granicami Kraju od września 1939 roku, t. 1-4, Lublin 1976.

Maty Rocznik Statystyczny 1939, Warszawa 1939.

Polska stużba zagraniczna po 1 września 1939 r., Londyn 1954.

Przewodnik po Palestynie, Tel-Awiw 1942.

Steimatzkiego przewodnik po Palestynie, Jerozolima 1942.

The Middle East: A Political and Economic Survey, ed. Royal Institute of International Affairs, London-New York 1950.

The Statesman's Year-Book. Statistical and Historical Annual of the States of the World for the year 1947, ed. S.H. Steinberg, London 1947.

Artur Patek, prof. dr hab.; pracownik Instytutu Historii UJ, kierownik Zakładu Historii Powszechnej Najnowszej; główne zainteresowania badawcze: historia powszechna XX wieku ze szczególnym uwzględnieniem Bliskiego Wschodu i dziejów Polonii. Ważniejsze publikacje: Birobidżan. 
Sowiecka Ziemia Obiecana? Żydowski Obwód Autonomiczny w ZSRR (1997); Wielka Brytania wobec Izraela w okresie pierwszej wojny arabsko-izraelskiej, maj 1948 - styczeń 1949 (2002); Jews on Route to Palestine 1934-1944. Sketches from the History of Aliyah Bet - Clandestine Jewish Immigration (2012); Polski cmentarz w Jafie. Z dziejów Polonii w Izraelu (2016); Najnowsza historia świata 1945-2007, t. 1-4 (1997-2008; współautor). 